\title{
Anatomy in forensics: applications and need for collaboration
}

\begin{abstract}
Anatomical Sciences are important in medical and forensic education and investigations. Areas of Anatomical Sciences which are important in forensic education and investigations have been highlighted and discussed. Therefore there is need for collaboration among Anatomist who are interested in forensic education and investigations with other Forensic Scientists. This collaboration will create opportunity for exchange of ideas required for proper investigations in Forensics as well as employment opportunity.
\end{abstract}

Keywords: anatomical sciences, collaboration, investigations, forensics
Volume 5 Issue I - 2017

\author{
Ekezie Jervas \\ Department of Anatomy, Federal University of Technology, \\ Nigeria \\ Correspondence: Ekezie Jervas, Department of Anatomy, \\ School of Basic Medical Sciences, Federal University of \\ Technology P.M.B 1526, Owerri, Nigeria, Tel 234806 5430037, \\ Email ekeziejervas@gmail.com
}

Received: May 03, 2017 | Published: June 09, 2017

\begin{abstract}
Abbreviations: DNA, deoxyribonucleic acid; SMARCAD1gene, SWI/SNF-related, matrix-associated actindependent regulator of chromatin, subfamily a, containing DEAD/H box 1; DIOF, distance between the infraorbital foramina; DRIOF, distance from the right infraorbital foramen to the nasion; DLIOFN, distance from the left infraorbital foramen to the nasion; IOFs, infraorbital foramina; FM, foramem magnum; LRC, occipital condyle; MnID, minimum intercondylar distance; WFM, width of the foramen magnum
\end{abstract}

\section{Introduction}

The term Human Anatomy deals with the way the parts of the human body, right from molecules, interact to give rise to cells and tissues which interact and relate to form a complete and complex functional unit - the human body. It has two major parts: Microscopic Anatomy and Macroscopic Anatomy. Its history can be traced from the earliest examinations of sacrificial victims to the more complex analysis of the human body done using modern devices and tools to study the organs, tissues and cells, living or dead, in more details aimed at solving clinical problems and other needs of the society like forensic investigation. Forensic anatomy-a new emerging field, tries to determine, examine and identify preserved or unpreserved body parts of the human remains, as well as the living, consequent upon which the big fours of Forensic Anthropology (i.e. sex, age, race and stature) is established. It also examines the cause of death.

From a molecular point of view, atoms interact to form molecules and the integration of molecules gives rise to organelles seen in the cell. The deoxyribonucleic acid (DNA) - a chain of nucleotides (a type of nucleic acid with four different chemical groups called bases), and a part of the genetic makeup of an individual can be accessed from any part of the human structure like the hair, blood, bone, etc. The DNA, when isolated from any given part/structure of the human body and further examined, is always unique for a particular person. In this way the interaction of human part at the molecular level is essentially necessary in the identification process, in case of crime, because the evidence (hairs, blood, saliva, bone fragment, semen etc) that a suspect leaves at a crime scene is a vital tool for crime investigation and detection. Kamoun and colleagues in their study used the combination of two DNA extraction methods (phenol-chloroform + DNA IQ ${ }^{\mathrm{TM}}$ ) to improve the quality of DNA extracted from putrefied teeth and skull bone for identification purposes. ${ }^{1}$ More recently, the DNA can be used as a biometric tool to classify and guide the identification of unknown individuals or biological samples such as hairs, blood, saliva, bone fragment, semen, etc $^{2}$ left at crime scene. Forensic DNA profiling is the analysis of DNA molecule using computer systems ${ }^{3}$ and this aims to reveal suspected criminals at molecular level.

\section{Role of embryology in fingerprinting, footprints and other body prints}

The knowledge of embryology, a branch of Anatomy, is also applicable in forensic studies. For instance, the establishments of the epidermal ridge pattern take place from the 10th to 16th weeks of development. ${ }^{4-8}$ Accordingly, the 11th week marked the period of formation of primary ridges. According to $0^{4,7,9}$ these establish the future surface patterns which become well pronounced at the 16th week. Notably, the patterns of fingerprints are encoded at the interface between the dermis, and such pattern cannot be destroyed by surface skin injuries and thus remain unchanged throughout life. ${ }^{10}$ Scientists have suggested a number of factors responsible for the patterning and formation of fingerprints. These factors include: SMARCADlgene, ${ }^{11}$ Volar pad, ${ }^{12}$ Genetic factor, ${ }^{13,14}$ Boundary effects, and Markel cells. ${ }^{15}$

From the knowledge above, researchers have documented three basic patterns of fingerprint ridges. ${ }^{16-20}$ These basic fingerprint ridge patterns are: arch (plain and tented), loop (radial and ulna), and whorl (plain and others). The arch is a pattern where the ridges enter form one side of the finger, rise in the centre forming an arc, and then exit the side of the finger. The loop is a pattern where the ridge enters from one side of a finger forms a curve and tend to exit from the same side from which they enter. In the whorl pattern, ridges form circularly around a central point on the finger. ${ }^{21,22}$ This gives rise to the term dermatoglyphics which was coined by. ${ }^{23}$ Dermatoglyphics is derived from a Greek word 'derma' meaning skin, and 'glyphics' meaning 
carvings. ${ }^{24}$ Dermatoglyphics is the scientific study of epidermal ridges and their configuration on the palmer surface of the hand and fingers, and the plantar surface of the foot and toes. ${ }^{25,26}$ The hereditary basis of dermal patterns was first reported. ${ }^{27,28}$

In addition to fingerprints, footprints, ear prints, and lip prints also follow the dermal pattern. Footprints are the impressions that a person leave in the earth or on surface after walking on it or making contact with it. Notably, shoes and bare feet can leave footprints in soft or semi-soft surfaces and the impression can last for a couple of minutes to hundreds of years and when recovered from a crime scene and further examined and interpreted can help the prosecution secure a criminal conviction. ${ }^{29}$ For instance, stature has been estimated from footprints, handprints and even from a shoe left at the scene of crime. ${ }^{30,31}$ Estimation of stature from these imprints provides import evidence in crime investigation. Also Krishen measured bilateral footprints of 1040 males, of Gujjars of North India for ten and eight measurement and noted significant and positive correlation between stature and measurement of footprints and foot outlines ( $p<0.001$ and $\mathrm{p}<0.01)$ except toe $1-5$ angle of declination which shows correlation coefficient. ${ }^{32}$ Lip prints are wrinkles and grooves seen in the zone of transition of human lip between the inner labial mucosa and outer skin. Like the fingerprints, its appearance varies from individual to individual ${ }^{33}$ and forms a veritable tool in crime dictation. The study of lip prints is known as cheiloscopy ${ }^{33}$ named by Tsuchihashi as 'sulci labiorum rubrorum'. ${ }^{34}$ Many classifications have been proposed for lip prints ${ }^{35}$ but that of Suzuki and Tsuchihashi is the most common classification scheme being used. ${ }^{36}$ The classification includes:

i. Type I: Clear-cut vertical grooves that run across the entire lips;

ii. Type I': Similar to type I, but the grooves do not cover the entire lip;

iii. Type II: Branched grooves;

iv. Type III: Intersected grooves;

v. Type IV: Reticular grooves;

vi. Type V: Grooves do not fall into any of the types I-IV and cannot be differentiated morphologically (undetermined).

\section{Role of biometry}

The prints (fingerprints, palm prints, footprints, ear prints and lip prints) are dermal impressions left on surfaces. Any of the prints can be recovered from crime scene and forms a tool that aid forensic investigators in crime dictation. In Biometric technology, the prints are seen, collected, studied, evaluated and compared with stored data and an exact cross match with suspects aids in the identification of the culprit. Therefore, Biometrics as a tool in forensic investigation should not only be seen as a physiological and behavioral features but also an anatomical feature because both the physical/ anatomical features (finger prints, face, hand/finger geometry, iris, retina, ear, etc.) and behavioral characteristics (signature, voice, gait, odor, etc.) are automated to generate information that will help in the dictation of the suspect. The biometric system therefore, is a pattern recognition device that acquires physical or behavioral data from an individual, extracts a salient feature set from the data, compares this feature set against the features set stored in the database and provides the result of the comparison. ${ }^{2}$

\section{Role of osteology}

The scientific study of the morphology and pathology of bones is called osteology. It is a branch of Anatomy whose knowledge is of great importance in stature/height estimation. Ultimately, Anatomical land marks are employed by Anatomist and Forensic Anthropologist in the stature estimation process. This is done through osteometric and somatometric evaluation of bones. Anatomical Landmarks are features seen on humans' structure that are useful for descriptive and identification purposes. Using physical markers present on skeleton, forensic anthropologists can possibly ascertain a victim's age, sex, stature, and ancestry/race i.e. the big fours of Forensic Anthropology. ${ }^{37}$ The pelvis $\mathrm{s}^{38,39}$ and skull ${ }^{40}$ are commonly used for sex determination. Anatomical landmarks seen on the skull for such determinations include temporal line, the eye sockets, the supraorbital ridge ${ }^{41}$ nuchal lines, and the mastoid process and zygomatic bone..$^{42}$ Other craniometric points include: Pterion, Lambda, Bregma, Vertex, Asterion, Glabella, Inion and Nasion..$^{42}$ Recently, ${ }^{37}$ in their study noted thatForamem magnum (FM) dimensions are very important anatomical landmark in sex determination among the Sudanese population. Morphometric analysis using modern radiological techniques such as CT increases the accuracy of sex prediction, and, moreover, decreases the need for defleshing and classical autopsy. Among all FM variables, the Length of Right Occipital Condyle (LRC), Minimum Intercondylar Distance (MnID), and Width of the Foramen Magnum (WFM) could determine sex using specific equation with an accuracy rate of $83 \%{ }^{37}$ In a study to determine sexual dimorphism in Brazilian skulls from measurements of the area of the triangle formed between lines joining the IOFs to the nasion, 242 human skulls belonging to the Study and Research Center for Anatomy and Forensic Anthropology of Tiradentes University were used. ${ }^{43}$ Observation showed that out of the 242 skulls examined, 148 were male and 94 were female, with ages ranging from 18 to 91 years. The area of the triangle formed by the lines connecting the IOFs to the nasion in the male skulls ranged from 944.6 to $1105.3 \mathrm{~mm}^{2}$ (mean: $1023.9 \mathrm{~mm}^{2}$ ). In the female skulls, it ranged from 853.8 to $1025.3 \mathrm{~mm}^{2}$ (mean: $946.5 \mathrm{~mm}^{2}$ ). In relation to sex, the authors noted that there were statistically significant differences in the measurements of DIOF, DRIOFN, DLIOFN and the perimeter and area of the triangle delimited by the infraorbital foramina and the nasion and a multivariate difference in measurements. Thus a sexual dimorphism occurred in all measures and area that formed the triangle between the infraorbital foramen and the nasion that were larger in males. ${ }^{43}$

Furthermore, Anatomical landmarks are very useful in the grouping of ancestors into the three historical groups: Caucasoid, Mongoloid, and Negroid. The bone mainly used in this aspect is the maxilla which ancestrally has three shapes/groupings. These shapes include: hyperbolic, parabolic, and rounded. However, interracial/ intercontinental marriage makes the shape/markers to become less defined and grouping may be difficult. ${ }^{44}$ Other Anatomical landmarks that are useful in accessing the ancestry of a given individual are the nasal openings and zygomatic arch..$^{45}$ As noted above, in stature estimation the knowledge of osteology is very important. The long bones of the limbs and the bones of the hand and foot have been used by many researchers to estimate stature. The long bones of the limbs are the most widely used to regress on body height. ${ }^{46-50}$ The upper extremity digit length and palm lengths have also been used to regressed stature ${ }^{51}$ as well as the foot to predict sex. ${ }^{52}$ In addition, estimation of height and sex could be determined from 
the combination of the dimensions of short bones of the body. For example,,$^{53}$ estimated the height and sex of Nigerian subjects by combining the dimensions of the right and left hands and foot while ${ }^{54}$ carried out estimation of stature based on hand length, and tested all possible (simple and multiple) linear regression models for males, females and both genders. The multiple linear regression models for both genders together was found to be the best model with the highest values for the coefficient of determination R2 and R2 adjusted.

The relationship between specific body dimensions is also important in the identification of criminals and victims. In conditions where the available evidences are skeletal remains, anthropologists have put forward means to evaluate and estimate height from skeletal remains and even from fragmentary bones. ${ }^{55,56}$ According to ${ }^{57,58}$ the estimation of stature from incomplete skeletal and decomposing human appeared first in this field in the late 1800s. This is possible because extensive studies have established positive correlation between stature and lengths of bones ${ }^{47,59-61}$ and even stature and various body dimensions. ${ }^{62-64}$ In concordance to that, ${ }^{65}$ carried the following measurement: the length, width, malloli height, navicular height of the right and left foot as well as stature from 249 subjects of medical faculty of Dokuz Eylal University, Turkey, to develop formulae for the estimation of stature and gender of the subjects.

Stature has also been estimated from cephalo-facial anthropometry because in some situation, highly decomposed and mutilated dead bodies with fragmentary remains, mainly cephalo-facial regions may be brought for postmortem examinations. In this case, the only way to ascertain the 'Big Four '(age, sex, stature and race) of forensic anthropology is to use the available remains. With regards to that, krishan noted that all the cephalo-facial parameters were strongly and positively correlated $(\mathrm{p}<0.001)$ with stature in a study he carries out on 996 adult male of North Indians, aged 18 to 30 years. Measurements of the cephalic region have strong correlation than those of the facial region, because regression analysis showed that the cephalic region give better prediction of stature. ${ }^{66}$ Stature and sex could also be predicted from lateral cephalogram because lateral cephalogram is ideal for skull examination as it gives details of the anatomical points. Patil and Mody performed such cephalogram on Indian subjects and derived regression formulae using maximum length of skull, which showed very high degree of reliability for stature estimation in males as well as in females while 10 cephalometric variables provided $99 \%$ reliability in sex determination. ${ }^{67}$

Many researchers ${ }^{68,69}$ have proposed new methods for stature estimation from body dimension, based on stature subgroups (short, medium or tall). Their findings suggested that stature group-specific formular give more accurate estimates of height, and that this was particularly significant for individuals who were short or tall relative to the average of a population. Evidence has also shown that regression equation derived from sacroccygeal dimensions perform somewhat better than those based on foot did and head variables do, but worse than those based on longer bone length. Therefore, in the absence of long bone dimensions, sacral and coccygeal vertebrae dimensions have been documented to be useful in stature estimation. ${ }^{70}$ Furthermore, ${ }^{71}$ were able to estimate living stature from selected soft tissue (Anthropometric) measurements and concluded that stature estimates from soft tissue measurement provided good result and removed the necessity for dissection when working with fresh body portions during Forensic investigation.

\section{Conclusion}

Conclusively therefore, Anatomical sciences are vital in Forensic Science/education and investigations and Anatomists who are interested in Forensics should be allowed to participate. This will ultimately create opportunity and collaboration among Anatomists and other Forensic Scientists for exchange of ideas and for proper investigations having highlighted areas where Anatomical Sciences are important in Forensic science/investigation.

\section{Acknowledgments}

None.

\section{Conflicts of interest}

None.

\section{References}

1. Kamoun A, Amar WB, Mahfoudh N, et al. Extraction Strategy for DNA Recovery from Putrefied Teeth and Skull Bone. Arab J Forensic Sci \& Forensic Med. 2016;1(4):399-405.

2. Saini M, Kapoor AK. Biometrics in Forensic Identification: Applications and Challenges. J Forensic Med. 2016;1(2):1-6.

3. Dessimoz D, Champod C. Linkages between biometrics and forensic science. Handbook of biometrics, Springer, USA. 2008;425-459.

4. Babler WJ. Embryogenic development of epidermal ridges and their configurations. Birth Defects Orig Artic Ser. 1991;27(2):95-112.

5. Hale A. Morphogenesis of volar skin in the human foetus. Am J Anatomy. 1951;91(1):147-181.

6. Hirsch W, Schweichel JU. Morphological evidence concerning the problem of skin ridge formation. J Ment Defic Res. 1973;17(1):58-72.

7. Okajima M. Development of dermal ridges in the fetus. J Med Genet. $1975 ;(12): 234-250$.

8. Penrose LS, Ohara PT. The development of epidermal ridge. J Med Genet. 1973;10(3):201-208.

9. Kucken M, Newell AC. A model of fingerprints formation. Eur Physics Latter. 2004;68(1):141-146.

10. Manoj KS, Hemlata S. Dermatoglyphics as a diagnositic to predict diabetes: J Clin and Diag Res. 2012;6(3):327-332.

11. Adra CN, Donato JL, Badovinac R, et al. SMARCAD1, a novel human Helicase family-defining member associated with genetic instability: cloning, expression, and mapping to 4q22-q23, a band rich in breakpoints and deletion mutants involved in several human diseases. Genomics. 2001;69(2):162-173.

12. Bonnevie K. Was lehrt die embryologie der papillar muster uber ihre bedeutung als rassen-und familiencharakter. Part I and II. Z Inducts. Abstammver. 1929;(50):219-274.

13. Abue A, Duru F, Ibeabuchi NM Bassey R. Digito-palmer Dermatoglyphic Patterns of Asthmatics in Lagos, Nigeria. Open Science Repository Anthropology. 2012;23050401.

14. Abue A, Ujaddughe M, Kpela M. The Arch Pattern Dermatoglyphics on the Toes of Hausa Ethnic Group of Nigeria. Advances in Anthropology. 2013;3(4):237-239.

15. Kucken M, Newell AC. Fingerprints formation. J Theo Biol. 2005;235:7183. 
16. David TJ. Dermatoglyphs in congenital heart disease. J Med Ethics. 1981;18(1):344-349.

17. Trimpe T. Fingerprinting Basics, 8th grade forensic sciences. 2006.

18. Udoaka AI, Udoaka EG. Digital dermatoglyphics in Ijaw students of University of Port Harcourt, Nigeria. Cont J Biomed Sci. 2009;(3):1-5.

19. Osunwoke EA, Ordu KS, Hart J, et al. A Study on the Dermatoglyphic Patterns of Okrika and Ikwerre Ethnic Groups of Nigeria. Scientia Africana. 2008;7(2):143-147.

20. Anibor E, Eboh DEO, Okumagba MT, et al. Palmar and digital dermatoglyphic patterns of the Ijaws in Delta state of Nigeria. Arch Appl Sci Res. 2011;3(6):301-306.

21. Langenberg G. Are one's fingerprints similar to those of his parents in any discernable way? Scientific American, USA. 2005.

22. Henry ER. Classification and uses of fingerprints London. George Rutledge and Sonsm, UK. 1900;1-140.

23. Cummins H, Midlo C. Finger prints, palms and sole. Ann hum genetics. $1939 ; 72-75$.

24. Penrose LS, Loesch D. Topological classification of palmar dermatoglyphic. J Defi Rese. 1963;14(2):111-128.

25. Adebisi SS. Contemporary tools in Forensic Investigations. Inter J Biol Anthropol. 2008;4(1):5-7.

26. Adebisi SS. Fingerprint Studies the recent Challenges. Inter J Biol Anthropol. 2009;2(2):1-9.

27. Galton F. The patterns in thumbs and finger marks - on their arrangement into naturally distginctg classes, the permanence of the papillary ridges that make them and the resemblance of their classes to ordinary general. Philosophical Transactions of the Royal Soc of London. 1890;(182):1-23.

28. Wider HH. Racial differences in palm and sole configuration; Am J Anthropol Phy. 1925;6:244-248.

29. http://www.legalmatch.com/law-library/article/footprints-as-evidence. html

30. Gordon CC, Buikstra JE. Linear models for the prediction of stature from foot dimensions. J Forensic Sci. 1992;37(3):771-782.

31. Ashizawa K, Kumakura A, Kusumoto S, et al. Relative foot size and shape to general body size in Javanese. Ann Hum Biol. 1997;24(2):117-129.

32. Krishan K. Estimation of stature from footprint and outline dimension in Gujars of North India. Forensic Sci Int Dev. 2008;175(2-3):93-101.

33. Caldas IM, Magalhães T, Afonso A. Establishing identity using cheiloscopy and palatoscopy. Forensic Sci Int. 2007;165(1):1-9.

34. Metgud R, Kaur M, Naik S, et al. Correlation Between Lip Prints and Fingerprints in Gujrati Population-A Forensic Study. J Adva Med and Dental Sci Res. 2017;4(3):30-34.

35. Negi A, Negi A. The connecting link! Lip prints and fingerprints. $J$ Forensic Dent Sci. 2007;(8):177-178.

36. Suzuku K, Tsuchihashi Y. A new attempt of personal identification by means of lip print. J India Den Asso. 1970;42(1):8-9.

37. El Barrany UM, Ghaleb SS, Ibrahim SF, et al. Sex Prediction using Foramen Magnum and Occipital Condyles Computed Tomography Measurements in Sudanese Population. Arab J Forensic Sci \& Forensic Med. 2016;1(4):414-423.

38. Dixit SG, Kakar S, Agarwal S, et al. Sexing of human hip bones of Indian origin by discriminant function analysis. J Forensic Leg Med. 2007; 14(7):429-435.
39. Gómez Valdés JA, Quinto Sánchez M, Menéndez Garmendia A, et al. Comparison of methods to determine sex by evaluating the greater sciatic notch: Visual, angular and geometric morphometrics. Forensic Sci Int 2012;221(1-3):1-7.

40. Guyomarc'h, P Bruzek J. Accuracy and reliability in sex determination from skulls: a comparison of Fordisc(R) 3.0 and the discriminant function analysis. Forensic Sci Int. 2011;208(1-3):1-6.

41. http://forensicoutreach.com/library/4-ways-to-determine-sex-when-allyou-have-is-a-skull/

42. Keith LM, Arthur FD, Argur Anne M. Clinically Orientated Anatomy. 6th edn. Lippincott Williams \& Wilkins. 2010;1-828.

43. Aragão JA, Silveira MPM, Cisneiros de Oliveira LCS, et al. Determination of Sexual Dimorphism from the Area of the Triangle. MOJ Anatomy \& Physiol. 2017;3(3):00091.

44. Anthropological Views. National Institute of Health.

45. Activity: Can you identify Ancestry?. Smithsoni National Museum of natural History.

46. Han TS, Lean ME. Lower leg length as an index of stature in adults. Int $J$ Obes Relat Metab Disord. 1996;20(1):21-27.

47. Donini LM, De Felice MR, de Bernardini L, et al. Prediction of stature in Italian elderly. $J$ Nutr Health Aging. 2000;4(2):72-76.

48. Mall G, Hubig M, Butter A, et al. Sex determination and estimation of stature from the long bones of the arm. Forensic Sci Int. 2001;117(12):23-30.

49. Mahakkanukrauh $\mathrm{P}$, Khanpetch $\mathrm{P}$, Prasitwattanseree, et al. Stature estimation from long bone lengths in a Thai population. Forensic Sci Int. 2010;210(1-3):1-7.

50. Ekezie J, Anibeze CIP, Uloneme GC, et al. Somatometric Evaluation of Long Bones of the Upper Extremity: A Forensic Tool. Forensic Res Criminol Int J. 2015;1(5):00029.

51. Jervas E, Ikechukwu Patrick AC, Chinedu AF, et al. Stature estimation using right digits and palm length in IGBO population, Nigeria. Ann Bioanthropol. 2014;2(1):23-28.

52. Bob Manuel IF Didia BC. Sexual Dimorphism In Foot Dimensions Among Adult Nigerians. The Internet J Biol Anthropol. 2009;3(1):1-6.

53. Danborno B Elupko A. Sexual dimorphism in hand and foot length, indices, stature-ratio and relationship to height in Nigerians. Int J Foren Sc. 2008;3(1):1-5.

54. Sanli SG, Kizilkanat ED, Boyan N, et al. Stature estimation based on hand length and foot length proportionate to stature. Clin Anat. 2005;18(8):589596.

55. Baduka P Nath S. Estimation of bones length and stature using fragmentary measures of humerus bones. Ind J Forensic Sci. 1989;3:23-25.

56. Baduka $\mathrm{P}$, Nath $\mathrm{S}$. Use the regression analysis in reconstruction of maximum bone lengths and living stature from fragmentary measures in ulna. Forensic Sci Int. 1990;45(1-2):15-26.

57. Ludy JK. Estimating living stature from skeletal remains. J Forensic Med. 1987;3(1-4):103-110.

58. Ozaslan A, Iscan MY, Ozaslan I, et al. Estimation of stature from body parts. Forensic Sci Int. 2003;132(1):1-6.

59. Athawale MC. Anthropological study of height from length to forearm bones: A study of one hundred Maharashtrian male adults of ages between five and thirty years. Am J Phy Anthropol. 1963;21:105-112. 
60. Mall G, Hubig M, Büttner A, et al. Sex determination and estimation of stature from the long bones of the arm. Forensic Sc Int. 2001;117(12):23-30.

61. Patel SM, Sha VG, Patel SV. Estimation of height from measurement of foot length in Gujarat region. J Ant Soc India. 2007;56(1):25-27.

62. Singh JS. Estimation of stature among the Meiteis. Paper presented in the first regional medico-legal conference and workshop on DNA profiling imphal. 2000.

63. Vein S, Nath S. Estimation of stature through hand and foot lengths Punjabi females of Delhi. South Asian Anthropo. 2000;21(2):67-71.

64. Hayperuma I, Nanayakkara G, Palahepittiya N. Prediction of stature based on the hand length. Galle Med J. 2009;14(1):15-18.

65. Zeybek G, Ergur I, Demiroglu. Stature and gender estimation using foot measurements. Forensic Sci Int Dev 2008;181(1-3):1-5.
66. Krishan K. Estimation of stature from cephalo-facial anthropometry in North India population. Forensic Sci Int 2008;181(1-3):1-6.

67. Patil KR, Mody RN. Determination of sex by discriminant function analysis and stature by regression analysis: a lateral cephalometric study. Forensic Sci Int. 2005;147(2-3):175-180.

68. Duyar I, Pelin C. Body height estimation based on tibia length in different stature groups. Am J Phys Anthropol. 2006;122(1):23-27.

69. Duyar I, Pelin C, Zagyapan R. A new method of stature estimation for forensic anthropological application. Anthrop Sci 2006;114:23-27.

70. Pelin C, Duyar I, Kayahan EM, et al. Body height estimation based on dimensions of sacral and coccygeal vertebrae. $J$ Forensic Sci. 2004;50(2):294-297.

71. Adams BJ, Herrmann N. Estimation of living stature from selected Anthropometric (soft tissue) measurement: Application for Forensic Anthropology. J Forensic Sci. 2009;54(4):753-760. 